\title{
HTLV-1 bZIP factor suppresses c-Fos transcription and impairs T cell activation
}

\author{
Akihiro Kawatsuki, Jun-ichiro Yasunaga, Masao Matsuoka \\ From 16th International Conference on Human Retroviruses: HTLV and Related Viruses \\ Montreal, Canada. 26-30 June 2013
}

c-Fos forms AP-1 heterodimer with JUN family proteins such as c-Jun and functions as a transcription factor to regulate diverse biological processes including $\mathrm{T}$ cell activation. Although an HTLV-1-encoded oncoprotein Tax induces the expression of c-fos, its expression is significantly down-regulated in fresh ATL cells compared with CD4+ T cells of healthy donors. In this study, we found that HTLV-1 bZIP factor (HBZ) is responsible for the suppressed $c$-fos transcription in ATL cells. The results of reporter assay implied the roles of LXXLL motif of HBZ on the suppression of $c$-fos. HBZ has been reported to suppress AP-1 and NFAT signaling pathways through the direct interaction with c-Jun and NFATc2, respectively. We found c-Fos overexpression impairs the suppressive effects of HBZ on AP-1 and NFAT, suggesting that HBZ overcomes the inhibitory effects of c-Fos by suppressing its transcription. HBZ is known to bind to c-Jun instead of c-Fos. Suppressed transcription of $c$-fos facilitates HBZ to interact with c-Jun, and enhances suppressive effect of HBZ on AP-1 pathway. AP-1 and NFAT signaling pathways are activated by $\mathrm{T}$-cell receptor (TCR) stimulation, leading to $\mathrm{T}$ cell activation. We found that TCR stimulation induces the $c$-fos up-regulation and the expression of the activation marker CD69 on CD4+ T cells of wild type mice, but not of HBZ transgenic mice, indicating that the activation of the signaling pathways initiated from TCR are suppressed by HBZ. We hypothesize that $c$-fos suppression by HBZ may contribute to impaired activation of $\mathrm{T}$ cells and pathogenesis of HTLV-1 infection.

Published: 7 January 2014

Laboratory of Virus Control, Institute for Virus Research, Kyoto University, Kyoto, Kyoto, Japan

(0) 2014 Kawatsuki et al; licensee BioMed Central Ltd. This is an Open Access article distributed under the terms of the Creative Commons Attribution License (http://creativecommons.org/licenses/by/2.0), which permits unrestricted use, distribution, and reproduction in any medium, provided the original work is properly cited. The Creative Commons Public Domain Dedication waiver (http://creativecommons.org/publicdomain/zero/1.0/) applies to the data made available in this article, unless otherwise stated.
Cite this article as: Kawatsuki et al:: HTLV-1 bZIP factor suppresses c-Fos transcription and impairs T cell activation. Retrovirology 2014 11(Suppl 1): P92.

Submit your next manuscript to BioMed Central and take full advantage of:

- Convenient online submission

- Thorough peer review

- No space constraints or color figure charges

- Immediate publication on acceptance

- Inclusion in PubMed, CAS, Scopus and Google Scholar

- Research which is freely available for redistribution Submit your manuscript at
www.biomedcentral.com/submit C Biomed Central
doi:10.1186/1742-4690-11-S1-P92

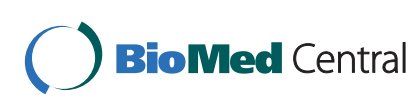

